\title{
What does literature teach about digital pathology? A bibliometric study in Web of Science
}

Jesús López-Belmonte. University of Granada. jesuslopez@ugr.es

Adrián Segura-Robles. University of Granada. adrianseg@ugr.es

William C. Cho. Queen Elizabeth Hospital, Hong Kong (China). williamcscho@gmail.com

María Elena Parra-González. University of Granada. elenaparra@ugr.es

Antonio J. Moreno-Guerrero. University of Granada. ajmoreno@ugr.es

\section{RESUMEN.}

La patología digital (DIPA) se ha convertido en una disciplina efectiva que genera un entorno gráfico para diagnosticar e interpretar la información patológica de las personas. Al analizar la literatura existente sobre DIPA, se produjo una brecha de conocimiento al no informar un estudio que ha analizado bibliométricamente las publicaciones sobre el tema. El objetivo de este estudio es analizar la producción científica y el rendimiento alcanzado por el término patología digital en la base de datos de Web of Science (WoS). Para ello, se ha llevado a cabo una metodología basada en la bibliometría, complementada con la técnica de mapeo científico para buscar, registrar, analizar y predecir la literatura científica sobre el estado de la cuestión. Hemos trabajado con una unidad de análisis de 1222 documentos reportados desde la base de datos de WoS. Los resultados muestran que no hay un tema de investigación en el campo de estudio de DIPA que se destaque del resto. Se puede observar una brecha conceptual en el desarrollo temático, dado que no hay un tema que se repita en todos los periodos, donde las conexiones son más temáticas que conceptuales. Hay documentos clave para diferentes temas. Los temas principales han sido muy diferentes a lo largo de los años como la telepatología y la inteligencia artificial.

PALABRAS CLAVE.

Análisis bibliométrico; patología digital; mapeo científico; producción científica; Web of Science.

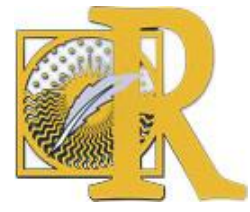




\section{ABSTRACT.}

Digital pathology (DIPA) has become an effective discipline that generates a graphic environment to diagnose and interpret the pathological information of people. When analyzing the existing literature on DIPA, a knowledge gap was produced by not reporting a study that has bibliometrically analyzed the publications on the subject. The objective of this study is to analyze the scientific production and performance achieved by the term digital pathology in the Web of Science (WoS) database. For this, a methodology based on bibliometrics has been carried out, complemented by the scientific mapping technique to search, recorder, analyze and predict the scientific literature on the state of question. We have worked with an analysis unit of 1222 documents reported from WoS database. The results show that there is no research topic in the field of study of DIPA that stands out from the rest. A conceptual gap can be observed in the thematic development, given that there is no theme that is repeated in all periods, where the connections are more thematic than conceptual. There are key documents for different topics. The main themes have been very different over the years like telepathology and artificial intelligence.

\section{KEY WORDS.}

Bibliometric analysis; digital pathology; scientific mapping; scientific production; web of science.

\section{Introduction.}

When we speak of digital pathology, we are referring to one of the branches of pathology (Fauzi et al., 2019), specifically that related to the management of data collected from information obtained through digital devices (Tavolara et al., 2019). For this purpose, it makes use of digital technologies, oriented in digital microscopes (Zaidi et al., 2019). These devices allow to visualize, manage, share and analyze the acquired data (Saxena and Goyal, 2019). Currently, digital pathology is booming in the field of medicine, specifically in diagnosis, with the intention of predicting diseases efficiently and cheaply (Majo et al., 2019).

Histopathology has played a significant role in providing a definitive diagnosis of the specimens, which provide important information for the clinical management of the patients. Conventionally, the process is done by microscopic methods and then examined by institutional or local pathologists. Digital pathology is making a paradigm shift in the whole process, it is a dynamic, image-based environment that enables the pathology information being acquisited, managed, shared and interpreted from a digitized glass slide. All this has caused great pressure in the diagnostic histopathology departments, to incorporate digital pathology as an indispensable diagnostic technology (Williams et al., 2019).

First of all, simple image acquisitions have now advanced to high-resolution, quantitative digitized whole-slide images (WSI) of tissue, which is virtual microscopy. It is well reported that there is a high diagnostic concordance between WSI and glass slides (Baidoshvili et al., 2018). Then the WSI can be further analyzed in a wild spectrum, for example, telepathology for discussing the diagnosis and interpretations with experts in the world, showing slides at tumor boards (Klimov et al., 2019).

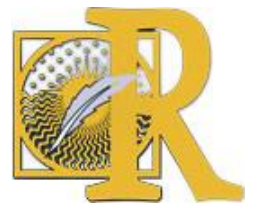


Digital pathology is rapidly gaining momentum as a proven and essential technology, including the primary diagnosis, diagnostic consultation, intraoperative diagnosis, medical student and resident training, manual and semi-quantitative review of immunohistochemistry, clinical research, diagnostic decision support and peer review. Digital pathology uses algorithms for the treatment of images obtained to be evaluated by computers that have specific software for this action (Mukundan, 2019).

With the aid of archival of pathology data, huge data can be acquired for big data analysis in using artificial intelligence (Al), machine learning and automation (Benke and Benke, 2018). The image data can be transformed into numerous features, pattern recognization and biomarker identification can be implemented. In digital pathology, hand-crafted feature-based methodologies shifted to Al-based feature management, mining of subvisual morphometric phenotypes is plausible. In this way, clinical, genomic and radiologic data of a patient being incorporating to predict the accuracy in diagnosing a disease. Both artificial intelligence and deep learning are increasing their incidence in health care with the intention of improving reporting and obtaining results in the clinical practices carried out (Bizzego et al., 2019).

With the support information technology infrastructure, staffing, and training, digital pathology has the potential to improve, treatment decisions, patient care, reduce the risk, streamline the pathology workflow in a more efficient, scalable and productive manner. However, in order to maintain high quality control, validation and standardization should be in place (Zwanenburg et al., 2020).

Digital pathology is also complemented by the application of digital holography to obtain cellular graphic information and have pertinent quantitative information for diagnosis (Norazman et al., 2019). Advances in digital pathology offer the possibility of analyzing slides of diseased tissue in order to report valuable information that allows the diagnosis and prognosis of people to be carried out (Naylor et al., 2018).

This research analyzes the term "digital pathology" (DIPA) in the scientific literature indexed in the Web of Science (WoS) database. This study has been developed through a scientific mapping, taking into account a series of bibliometric indicators, as well as a development of the structure and dynamism of the concept presented. To follow a model accepted by the scientific community, the analytical structure of previous studies taken from the Journal Citation Reports (JCR) has been followed (López-Belmonte et al., 2020).

The purpose of this study is to publicize the evolution of DIPA in the various publications registered in the main WoS collection. This is justified in the gap found in the scientific literature on the state of the question, in whose production there is no study analyzed with this bibliometric technique of documentary analysis. Therefore, this research focuses on the exploration of a field of knowledge in order to offer the scientific community new findings on the delimited construct. All this involves an advance in science, in addition to satisfying the need for knowledge of researchers focused on this topic of study.

The objectives of the present study focus on: a) To determine the performance of scientific production on DIPA; b) To know the scientific evolution of DIPA; c) To find out the most incidental issues about DIPA; d) To discover the most influential authors in DIPA.

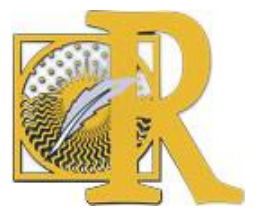

Fecha de recepción: 26-05-2020 Fecha de aceptación: 30-05-2020

López-Belmonte, J., Segura-Robles, A., Cho, W. C., Parra-González, M. E. \& Moreno-Guerrero, A. J. (2021) ¿Qué enseña la literatura sobre patología digital? Un estudio bibliométrico en Web of Science

International Journal of Educational Research and Innovation (IJERI), 16, 106- 121

ISSN: 2386-4303 DOI https://doi.org/10.46661/ijeri.4918 


\section{Materials and Methods}

\subsection{Research Design}

Bibliometry has been used as a research methodology to approach this study and achieve the formulated objectives. This methodological branch is based on the potential of scientometrics, in everything related to the search, registration, analysis and prediction processes of academic literature. This work has been developed following the guidelines of experts in this study method (Carmona-Serrano et al., 2021; López-Belmonte et al., 2019; Moreno-Guerrero et al., 2020; Rodríguez-García et al., 2019).

Specifically, this research has been based on an analysis of co-words and various bibliometric indicators and indices (h, g, hg, q2) (López-Núñez et al., 2020; Soler-Costa et al., 2021). This will give rise to a set of maps with nodes that will establish the performance and location of subdomains of the constructs connected to DIPA.

\subsection{Procedure and Data Analysis}

This research has materialized in various processes (Carmona-Serrano et al., 2020; LópezBelmonte et al., 2021): 1-Choice of the database to analyze (WoS); 2-Determination of the keywords to consider (digital pathology); 3-Elaboration of the search equation ("digital pathology"); 4-Selection of search bringing together the TOPIC process to report documents that had the concept to be analyzed in the metadata alluding to title, abstract and keywords. This produced a first data report of 1322 publications. The concept of DIPA was found for the first time in the scientific literature in 1991.

This study has included the analysis of a literary volume of 28 years (until 2019 inclusive). As exclusion criteria, the publications relating to $2020(n=51)$ have been deleted as the calendar year has not ended. Similarly, improperly indexed or repeated documents have been deleted $(n=49)$. This results in a final analysis unit of 1222 documents. These actions have been reflected in the following flow diagram, taking into account the protocols of the PRISMA-P matrix (Figure 1) (López-Belmonte et al., 2021; Segura-Robles et al., 2020).

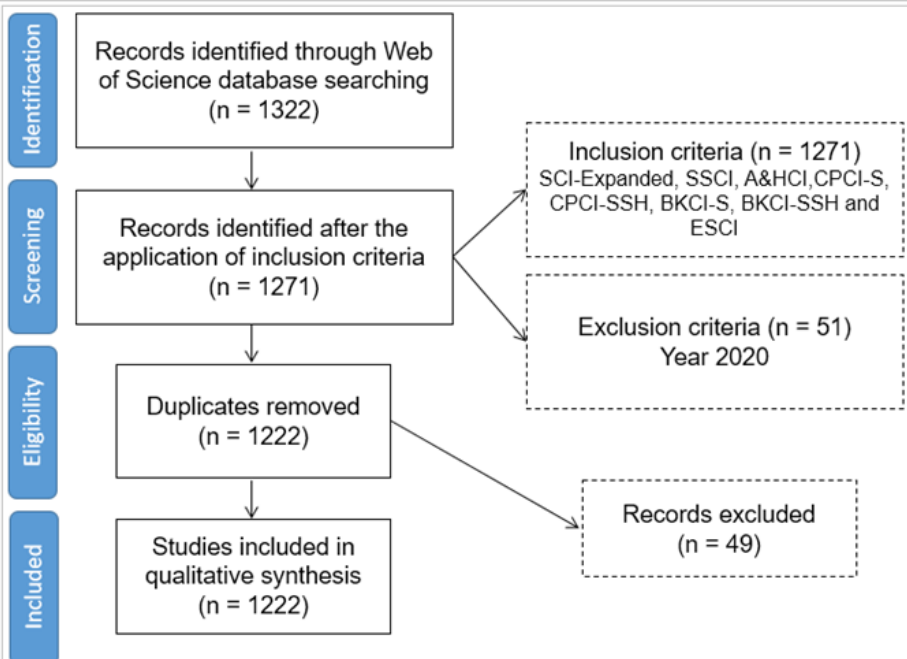

Figure 1. Flowchart according to the PRISMA Declaration.

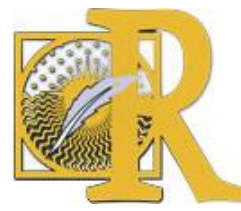

Fecha de recepción: 26-05-2020 Fecha de aceptación: 30-05-2020 López-Belmonte, J., Segura-Robles, A., Cho, W. C., Parra-González, M. E. \& Moreno-Guerrero, A. J. (2021) ¿Qué enseña la literatura sobre patología digital? Un estudio bibliométrico en Web of Science International Journal of Educational Research and Innovation (IJERI), 16, 106- 121 ISSN: 2386-4303 DOI https://doi.org/10.46661/ijeri.4918 
Furthermore, this production volume is derived from the application of certain production indicators and inclusion criteria (year of publication = all production except 2020), for not having concluded the calendar year, in such a way that the production of that year would not be significant. To carry out the analysis of the structural and dynamic development, SciMAT has been used for an effective co-word analysis, in which the following phases have been carried out (López-Belmonte et al., 2020; Parra-González et al., 2020):

- Recognition: in this phase the keywords of the documents are analyzed ( $n=3681)$, a map of co-occurrence nodes is generated, a standardized network of co-words is developed, the most significant keywords are detected $(n=3507)$ and the most common themes and concepts are represented by means of a clustering algorithm (MorenoGuerrero et al., 2020).

- Reproduction: at this time, a strategic diagram and a thematic network are made based on the principles of centrality and density. The graphs originating from this present four areas: upper right $=$ motor and relevant issues; top left = rooted and isolated themes; bottom left = missing or booming issues; lower right = poorly developed and cross-cutting themes (López-Belmonte et al., 2020).

- Determination: in this phase the evolution of the nodes spread over various periods or time intervals is analyzed. Five periods have been articulated in this study $(\mathrm{P} 1=1991$ 2011; P2 = 2012-2015; P3 = 2016-2017; P4 = 2018; P5 = 2019). However, for authorship, only a single period has been configured that has spanned its entire existence $(\mathrm{PX}=1991-2019)$. To find the strength of association, the number of common keywords in the different periods is taken into account (Carmona-Serrano et al., 2021).

- Performance: in this phase various production indicators configured with different inclusion criteria were applied (Table 1) (López-Belmonte et al., 2020).

Table 1. Production indicators and inclusion criteria.

\begin{tabular}{|c|c|}
\hline Configuration & Values \\
\hline Analysis unit & Keywords authors, keywords WoS \\
\hline \multirow{2}{*}{ Frequency threshold } & Keywords: $\mathrm{P}_{1}=(2), \mathrm{P}_{2}=(3), \mathrm{P}_{3}=(2), \mathrm{P}_{4}=(2), \mathrm{P}_{5}=(2)$ \\
\cline { 2 - 2 } & Authors: $\mathrm{P}_{\mathrm{x}}=(6)$ \\
\hline Network type & Co-occurrence \\
\hline Co-occurrence union value threshold & Keywords: $\mathrm{P}_{1}=(2), \mathrm{P}_{2}=(2), \mathrm{P}_{3}=(2), \mathrm{P}_{4}=(2), \mathrm{P}_{5}=(2)$ \\
\cline { 2 - 2 } Normalization measure & Authors: $\mathrm{P}_{\mathrm{x}}=(3)$ \\
\hline Clustering algorithm & Equivalence index \\
\hline Evolutionary measure & Maximum size: 9; Minimum size: 3 \\
\hline Overlapping measure & Jaccard index \\
\hline
\end{tabular}

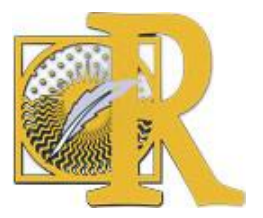

Fecha de recepción: 26-05-2020 Fecha de aceptación: 30-05-2020 López-Belmonte, J., Segura-Robles, A., Cho, W. C., Parra-González, M. E. \& Moreno-Guerrero, A. J. (2021) ¿Qué enseña la literatura sobre patología digital? Un estudio bibliométrico en Web of Science International Journal of Educational Research and Innovation (IJERI), 16, 106- 121 ISSN: 2386-4303 DOI https://doi.org/10.46661/ijeri.4918 


\section{Results.}

In this study, a disparate evolution of the study theme is observed. Between the first period (1991-2011) and the second period (2012-2015), we can see a base established in the DIPA study, given that its coincidence index is high, but from 2015 onwards, in the three remaining periods, the level of coincidence drops, which shows new fields of study by the educational community (figure 2).

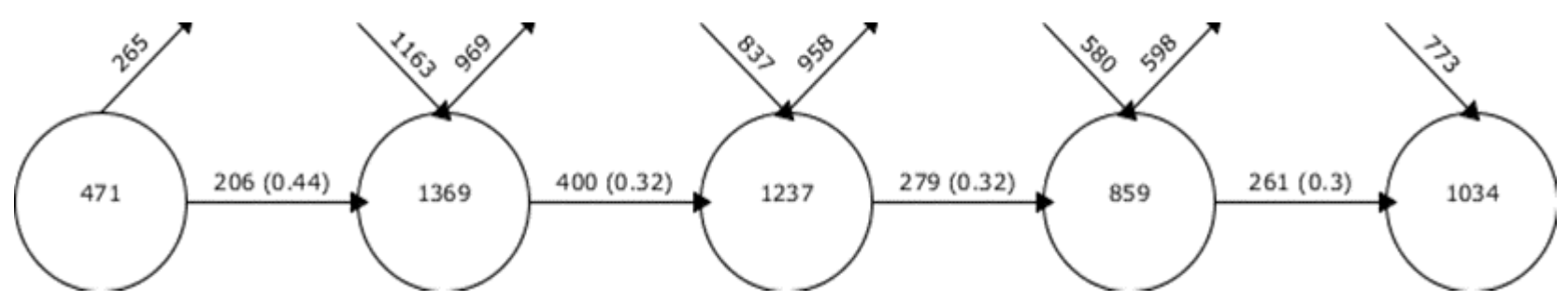

Figure 2. Continuity of keywords between contiguous intervals.

In the first period established (1991-2011), the topic with the highest bibliometric indicator is "telepathology", followed, at a great distance, by "breast-cancer". In the second period (20122015), the theme with the largest bibliometric indicator is "digital-pathology", followed, at a fairly large distance, by "expression". In the third period (2016-2017), the theme with the largest bibliometric indicator is "breast-cancer", followed, at a short distance, by "surgicalpathology". In the fourth period (2018), the theme with the highest bibliometric indicator is "cancer", followed at a very short distance by "whole-slide-imaging" and "pathology". In the last period, the theme with the highest bibliometric indicator is "artificial-intelligence" (Table 2).

Table 2. Thematic performance in DIPA.

\begin{tabular}{|c|c|c|c|c|c|c|}
\hline \multicolumn{7}{|c|}{ Interval 1991-2011 } \\
\hline Denomination & Works & h-index & g-index & Hg-index & q2-index & Cites \\
\hline Breast-cancer & 8 & 7 & 8 & 7.48 & 9.9 & 313 \\
\hline Telepathology & 33 & 18 & 29 & 22.85 & 25.81 & 918 \\
\hline Histopathology & 4 & 4 & 4 & 4 & 12.17 & 90 \\
\hline Cancer & 8 & 6 & 6 & 6 & 15.68 & 315 \\
\hline Prostate-Cancer & 6 & 6 & 6 & 6 & 12.25 & 171 \\
\hline Expression & 4 & 4 & 4 & 4 & 7.21 & 52 \\
\hline Diagnosis & 3 & 3 & 3 & 3 & 10.25 & 199 \\
\hline \multicolumn{7}{|c|}{ Interval } \\
\hline Denomination & Works & h-index & g-index & Hg-index & q2-index & Cites \\
\hline In-situ-hybridization & 17 & 11 & 16 & 13.27 & 15.91 & 666 \\
\hline Surgical-pathology & 26 & 14 & 23 & 17.94 & 19.8 & 805 \\
\hline Expression & 18 & 15 & 18 & 14.7 & 16.61 & 465 \\
\hline Digital-pathology & 101 & 50 & 37 & 27.2 & 28.98 & 1704 \\
\hline Carcinoma & 15 & 10 & 15 & 12.25 & 17.32 & 355 \\
\hline Prostate-cancer & 21 & 11 & 15 & 12.85 & 12.85 & 248 \\
\hline Microscopy & 13 & 6 & 10 & 7.75 & 16.79 & 346 \\
\hline
\end{tabular}

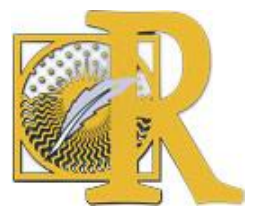



Un estudio bibliométrico en Web of Science

\begin{tabular}{|c|c|c|c|c|c|c|}
\hline System & 8 & 6 & 7 & 6.48 & 8.49 & 225 \\
\hline Phase-retrieval & 3 & 3 & 3 & 3 & 7.55 & 86 \\
\hline Prognostic-value & 4 & 3 & 3 & 3 & 12.37 & 233 \\
\hline Telecytology & 3 & 3 & 3 & 3 & 5.48 & 40 \\
\hline \multicolumn{7}{|c|}{ Interval 2016-2017 } \\
\hline Denomination & Works & h-index & g-index & Hg-index & q2-index & Cites \\
\hline Surgical-pathology & 15 & 9 & 14 & 11.22 & 10.39 & 205 \\
\hline Feature-stability & 6 & 4 & 5 & 4.47 & 6.63 & 41 \\
\hline Telepathology & 13 & 8 & 12 & 9.8 & 9.8 & 160 \\
\hline Breast-cancer & 52 & 14 & 31 & 20.83 & 23.66 & 1019 \\
\hline Inmunohistochemistry & 14 & 8 & 11 & 9.38 & 10.2 & 130 \\
\hline Pathology & 15 & 7 & 12 & 9.17 & 9.17 & 167 \\
\hline Cells & 13 & 7 & 13 & 9.54 & 9.17 & 202 \\
\hline Cancer & 11 & 6 & 7 & 6.48 & 6.48 & 58 \\
\hline Microscopy & 12 & 4 & 5 & 4.47 & 5.66 & 41 \\
\hline Histopathology & 3 & 7 & 9 & 7.94 & 8.37 & 151 \\
\hline Informatics & 3 & 1 & 2 & 1.41 & 1.73 & 4 \\
\hline Tumors & 3 & 2 & 3 & 2.45 & 12.96 & 120 \\
\hline Diagnostic-accuracy & 3 & 3 & 3 & 3 & 5.2 & 26 \\
\hline \multicolumn{7}{|c|}{ Interval 2018} \\
\hline Denomination & Works & $\mathrm{h}$-index & g-index & Hg-index & q2-index & Cites \\
\hline Laboratory-quality-center & 9 & 4 & 7 & 5.29 & 6.32 & 73 \\
\hline Expression & 6 & 3 & 6 & 4.24 & 6 & 42 \\
\hline Whole-slide-imaging & 22 & 5 & 10 & 7.07 & 7.75 & 107 \\
\hline Cancer & 21 & 9 & 16 & 12 & 13.08 & 269 \\
\hline Breast-cancer & 14 & 4 & 10 & 6.32 & 9.17 & 103 \\
\hline Pathology & 10 & 5 & 8 & 6.32 & 7.42 & 70 \\
\hline Image-analysis & 13 & 3 & 6 & 4.24 & 5.48 & 49 \\
\hline Deep-learning & 12 & 4 & 10 & 6.32 & 13.56 & 143 \\
\hline Prostate-cancer & 6 & 4 & 5 & 4.47 & 4.47 & 26 \\
\hline Virtual-slides & 5 & 3 & 5 & 3.87 & 4.58 & 26 \\
\hline Quantification & 4 & 2 & 2 & 2 & 2.83 & 8 \\
\hline Tumor-budding & 2 & 1 & 1 & 1 & 1.41 & 3 \\
\hline \multicolumn{7}{|c|}{ Interval 2019} \\
\hline Denomination & Works & $\mathrm{h}$-index & g-index & Hg-index & q2-index & Cites \\
\hline Artificial-intelligence & 30 & 6 & 7 & 6.48 & 6.48 & 70 \\
\hline Prognosis & 13 & 3 & 3 & 3 & 3 & 14 \\
\hline Whole-slide-images & 9 & 2 & 2 & 2 & 2.83 & 11 \\
\hline Classification & 36 & 5 & 8 & 6.32 & 6.71 & 97 \\
\hline Pathology & 13 & 3 & 4 & 3.46 & 4.24 & 20 \\
\hline Inmunotherapy & 8 & 2 & 5 & 3.16 & 5.29 & 27 \\
\hline Virtual-microscopy & 8 & 2 & 2 & 2 & 2.83 & 12 \\
\hline Diagnosis & 7 & 3 & 4 & 3.46 & 4.58 & 26 \\
\hline Expression & 5 & 1 & 1 & 1 & 1.41 & 4 \\
\hline Markov-random-field & 2 & 0 & 0 & 0 & 0 & 0 \\
\hline Camelyon & 2 & 0 & 0 & 0 & 0 & 0 \\
\hline Pathology-image & 2 & 0 & 0 & 0 & 0 & 0 \\
\hline Telecytology & 3 & 1 & 1 & 1 & 1.41 & 3 \\
\hline Progression & 3 & 1 & 1 & 1 & 1 & 1 \\
\hline
\end{tabular}

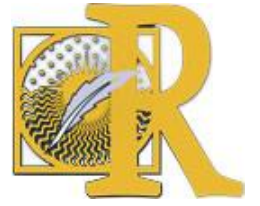




\section{$\Omega$ RESEARCH AND INNOVATION

The analysis of the five periods, only one theme is observed that is repeated as the driving theme, as is the case of "surgical-pathology" in the second and third periods. In the rest of the periods, the themes vary constantly. In the first period (1991-2011), the motor themes are "breast-cancer" and "telepathology". In the second period (2012-2015), the driving themes are "in-situ-hybrization" and "surgical-pathology". In the third period (2016-2017), the driving themes are "surgical-pathology"; "pathology" and "immunohistochemistry". In the fourth period (2018), the only motor theme is "laboratory-quality-center". In the last period (2019), the driving themes are "artificial-intelligence" and "virtual-microscopy". In the last period, the themes "progression" and "expression" should be kept in mind, given that they are located in the diagram as unknown themes, which may disappear or be considered as driving forces in the coming years (Figure 3).

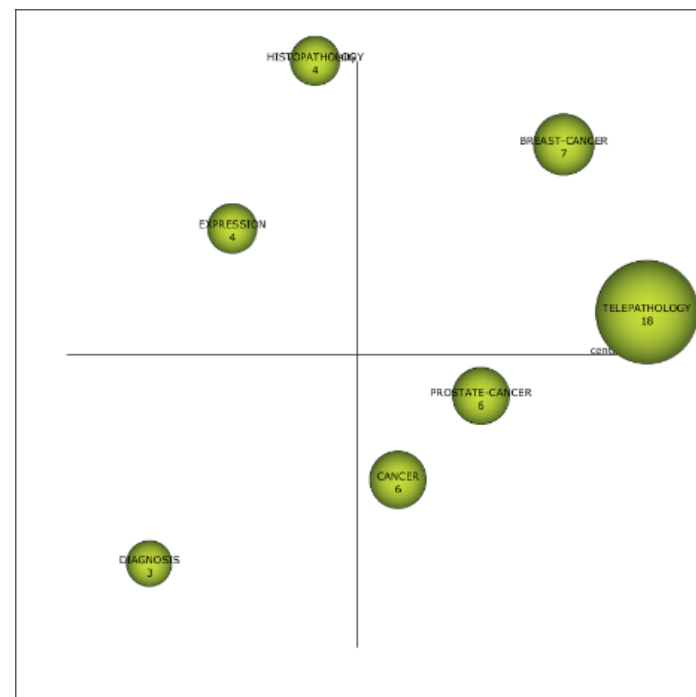

(a)

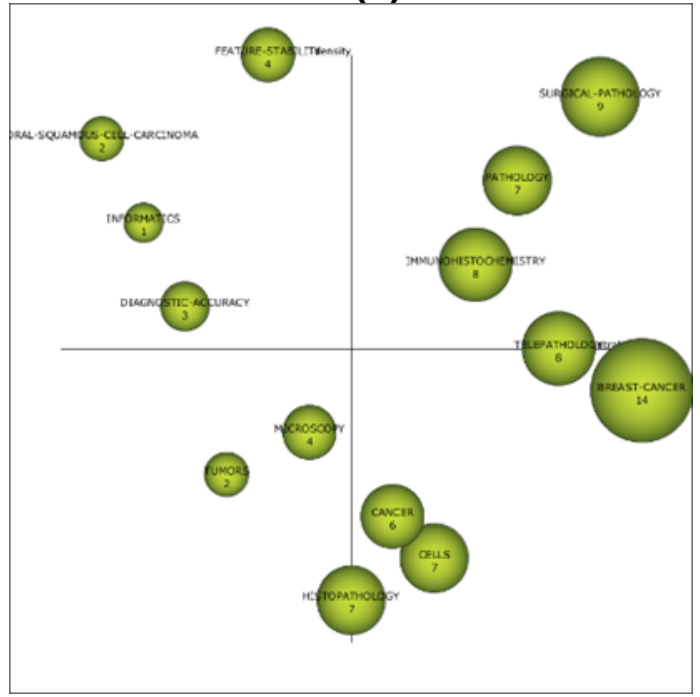

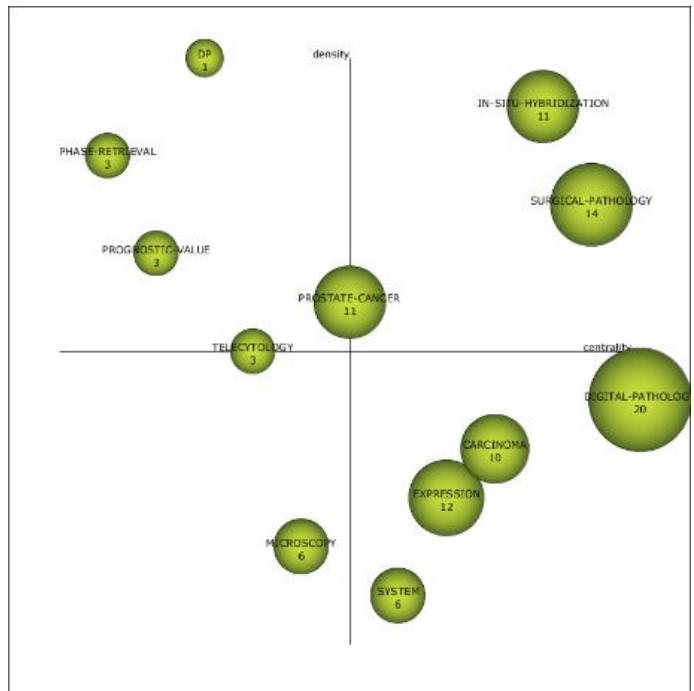

(b)

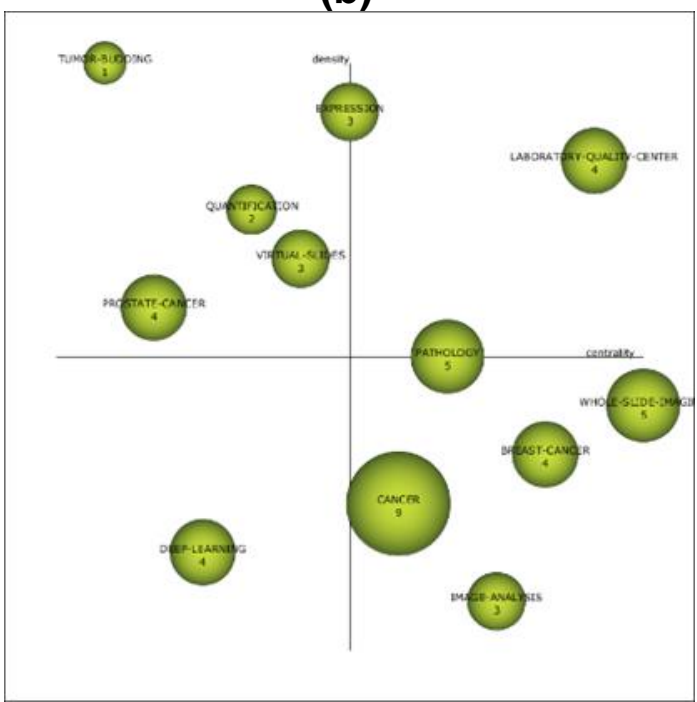

Fecha de recepción: 26-05-2020 Fecha de aceptación: 30-05-2020 
(c)

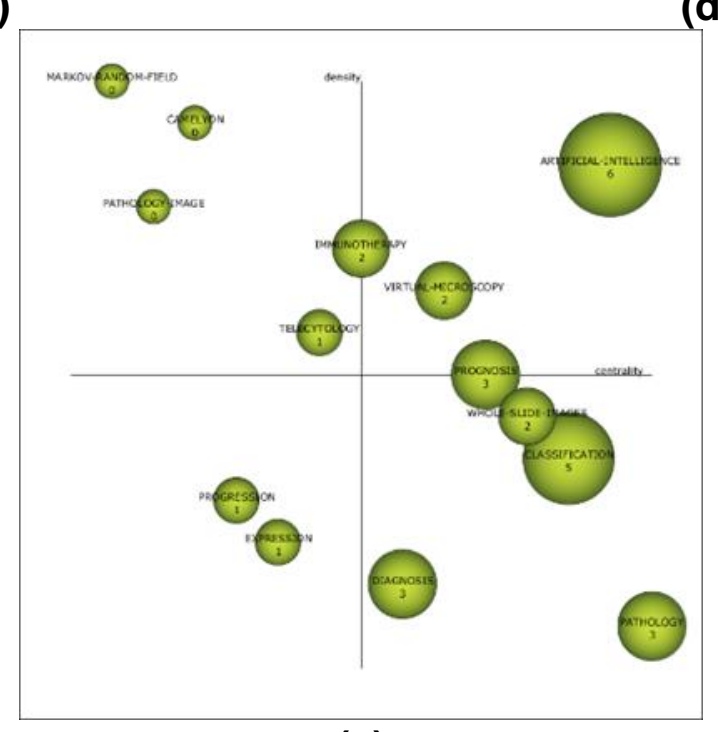

(d)

(e)

Figure 3. Strategic diagram by DIPA h-index.

Note: (a) Range 1991-2011; (b) Range 2012-2015; (c) Range 2016-2017; (d) Year 2018; (e) Year 2019.

\subsection{Thematic evolution of terms.}

Analyzing the data offered by figure 4, it is established that there is a conceptual gap in the field of study of DIPA, given that there is not one theme that is repeated in all the established periods. However, various key words such as "expression", "prostate-cancer" or "cancer" are observed to repeat several times in the different established time intervals. In this time diagram, there is no established and continuous line of research in which the scientific community bases its studies in this field. However, there is a line of research whose connection strength is medium-low, such as that established between "telepathology", "surgical-pathology", "surgical-pathology", "laboratory-quality-center" and "virtualmicroscopy". There is also a medium-low strength connection, such as that between "cancer" and "classification", and that between "prostate-cancer" and "progression", from the fourth and fifth periods. This figure also shows us that the connections are mostly thematic, since there are more continuous than discontinuous lines. As a noteworthy aspect, it can be determined that there is an evolution in this field of study, given that there is a move from more primitive technological fields, such as "telepathology", to more advanced technological aspects, this being reflected in artificial intelligence, with cancer being the main focus of attention.

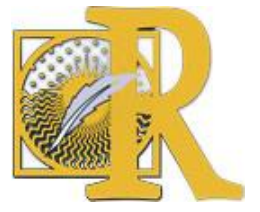




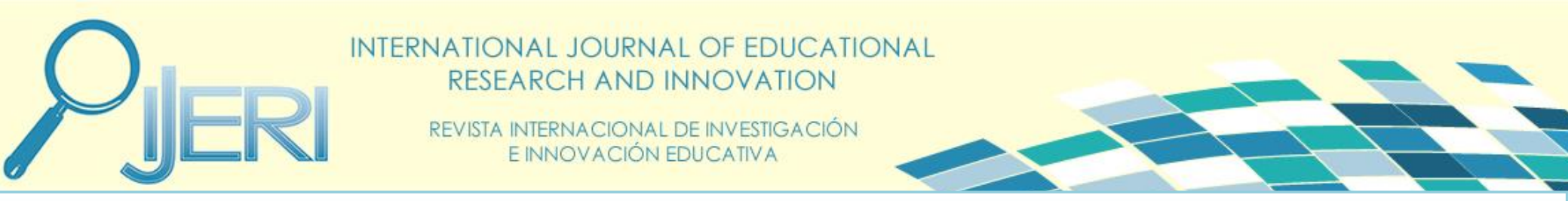

Jesús López-Belmonte, Adrián Segura-Robles, William C. Cho, María Elena Parra-González \& Antonio J. Moreno-Guerrero. ¿Qué enseña la literatura sobre patología digital? Un estudio bibliométrico en Web of Science

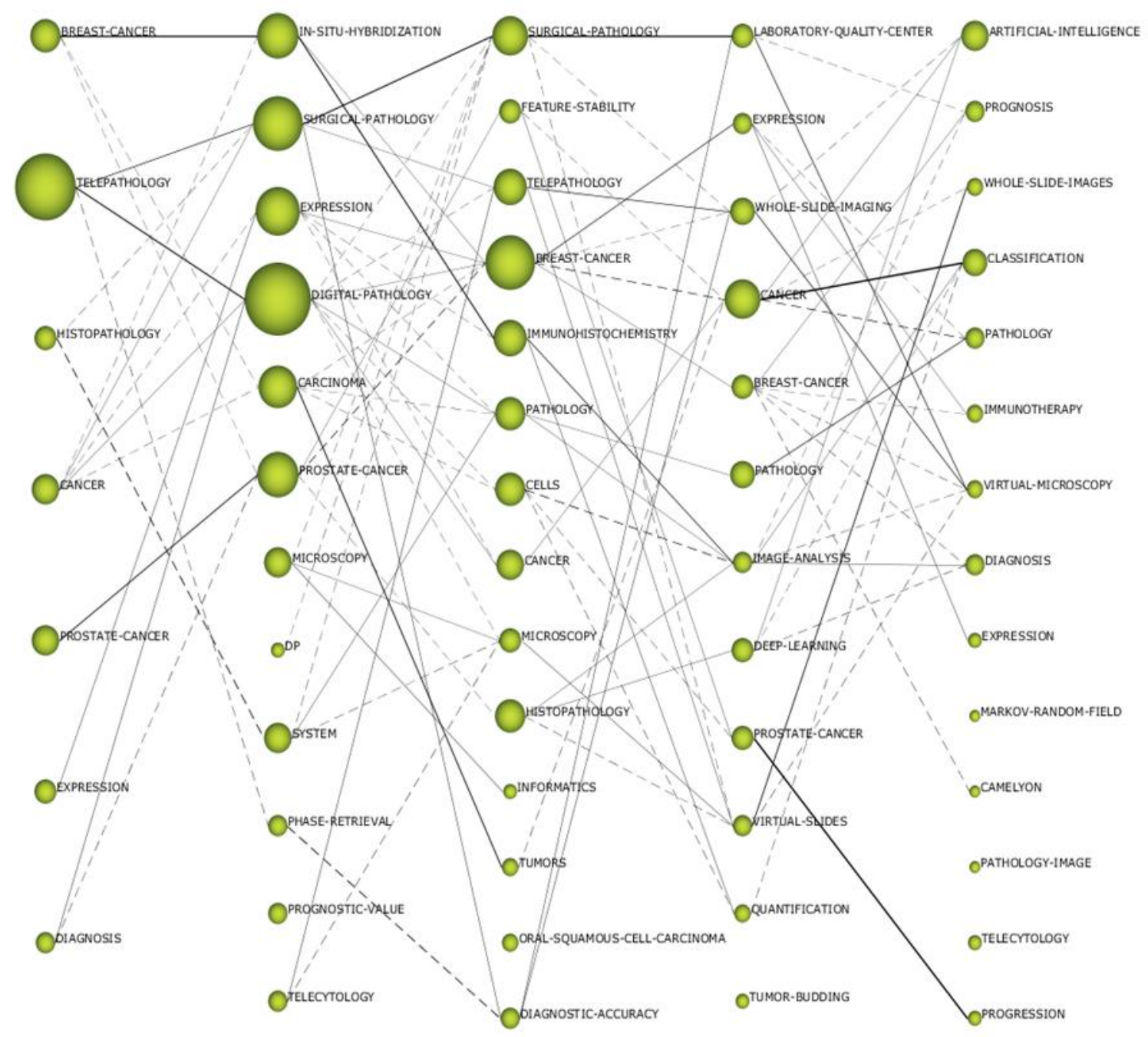

Figure 4. Thematic evolution by h-index.

\subsection{Authors with the highest relevance index.}

The authors considered as driving forces in the field of DIPA study are Madabhushi, A. Corredor, G., and Lugli, A. In addition, one should bear in mind the author Rajpoot, N., who can be considered in the future as a relevant author in the field of study (figure 5). 
Figure 5. Strategic diagram of authors of the entire production.

\section{Discussion and Conclusions.}

Digital pathology is a branch of pathology related to the handling of data collected from information obtained through digital devices. For this purpose, it makes use of digital technologies, oriented in digital microscopes, which allow visualizing, managing, sharing and analyzing the acquired data (Fauzi et al., 2019; Majo et al., 2019; Saxena et al., 2019; Tavolara et al., 2019; Zaidi et al., 2019). Currently, digital pathology is immersed in a paradigm shift, which affects and includes in the diagnoses that are being produced (Baidoshvili et al., 2018; Benke and Benke, 2018; Dash et al., 2019; Klimov et al., 2019; Mukundan, 2019; Williams et al., 2019). In addition, the procedure developed in the field of digital pathology involves multidisciplinary work, which is influenced by various agents and factors, in order to properly develop the procedure (Norazman et al., 2019; Zwanenburg et al., 2020).

The profile of research focused on "digital pathology" is: constant and growing evolution from 2010 onwards. The main language is English, the most productive country is the United States and the type of document is the article. The authors considered to be the driving force are

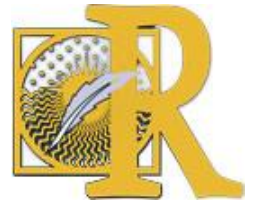


Madabhushi, A., which is also the most productive, Corredor, G., and Lugli, A. The area where more research is collected is "pathology". The main institution on the subject of study is the Pennsylvania Commonwealth System of Higher Education PCSHE. The main scientific journal is Virchows Archiv. The most cited document is that of Litjens and his team, with a total of 1264 citations received.

The coincidence of key words in the established periods shows a high index of coincidence, which shows a line of research based on time. It is true that this coincidence gradually decreases over the years, which can show new trends in a short period of time. This may be due to technological progress, which is improving at a dizzying rate.

The motor themes existing in each of the established periods show a variety of interests on the part of the scientific community. In the first period it was "telepathology", in the second period it was "digital-pathology". Already between these two periods, a change based on technological resources is shown, given that there is a move from "telepathology" to "digital", that is, there is a move from retro to modern. In the third period, the theme is "breast-cancer". In the fourth period it is "cancer". This shows that from 2016 to 2018, research is focused mainly on the disease, not on the resource used for its analysis and diagnosis. In the year 2019 the resource appears again, being the subject with more bibliometric indicator "artificialintelligence".

In addition, the driving themes in each of the periods should be kept in mind. It is one thing to know the themes with the highest bibliometric indexes, and on the other hand the themes with the most interest and relevance for the scientific community. In this case, in the first period the driving themes are "breast-cancer" and "telepathology". In other words, technology is mixed with the disease itself. In the second period, the motor themes are "in-situ-hybrization" and "surgical-pathology", and in the third period it is "surgical-pathology", "pathology" and "immunohistochemistry". In this case, the trends in research are oriented towards the patients' own pathologies. In the fourth period it is "laboratory-quality-center", and in the fifth period it is "artificial-intelligence" and "virtual-microscopy", this means that the focus is again on technological resources. In other words, the evolution of the field of research on "digital pathology" has varied between studies on technological resources for diagnosis and on the diseases in which technological resources have been used.

Also, analyzing the thematic evolution, a conceptual gap is observed, since the same subject is not repeated in all the established periods. But there are themes that are usually repeated continuously, among which is cancer. There is also a line of research that can be seen over time, such as "telepathology", "surgical-pathology", "surgical-pathology", "laboraty-qualitycenter" and "virtual-microscopy". In other words, the most established line of research is that based on technological resources. In addition, low-medium strength connection lines are observed, such as cancer and its diagnostic processes.

It can be concluded that research on "digital pathology" has evolved over time. On the one hand, there has been a shift from studies based on primitive technological resources to research oriented towards technological devices that are the latest in scientific progress. In other words, there has been a shift from the old to the modern. But this scientific evolution has not only focused on the technological resources used for diagnosis, but has evolved by alternating with the diagnosis of diseases. In other words, the scientific community has varied

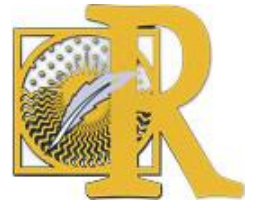

Fecha de recepción: 26-05-2020 Fecha de aceptación: 30-05-2020

López-Belmonte, J., Segura-Robles, A., Cho, W. C., Parra-González, M. E. \& Moreno-Guerrero, A. J. (2021) ¿Qué enseña la literatura sobre patología digital? Un estudio bibliométrico en Web of Science

International Journal of Educational Research and Innovation (IJERI), 16, 106- 121

ISSN: 2386-4303 DOI https://doi.org/10.46661/ijeri.4918 
between the technological and the diagnostic. Furthermore, it should be pointed out that cancer is currently the reference disease in the field of "digital pathology".

In short, the type of study presented represents an advance in the field of knowledge on the state of the question. In this case, the production and development that Digital Pathology has reached in the WoS database is presented. With the results revealed here, other researchers interested in this topic may know the entire literary projection.

The prospective of this research consists of providing researchers with new trends on the most relevant topics for the scientific community, as well as showing a state of the art that includes the key aspects on which other research has been based. This will allow them to start from a consolidated base to initiate, develop or guide their studies.

Last but not least, we must say that there are several limitations to this research. Firstly, there is the debugging of the data presented in the WoS, where repeated or unrelated papers are presented. Secondly, the establishment of the intervals, since the researchers have always tried to keep a similar number of papers in each of the intervals. Thirdly and finally, the parameters marked in this study have been established according to the researchers' own criteria. Thus, the results are presented according to their size and relevance. Thus, the data shown here should be analyzed with caution, since the change in the parameters established in this research may vary the amount and connections in the topics presented. As a line of future research, it is proposed that the study focus, in a mixed manner, between diagnosis and technological devices.

\section{References.}

- Baidoshvili, A., Stathonikos, N., Freling, G., Bart, J., Hart, N., Van der Laak..., Van Diest (2018). Validation of a whole-slide image-based teleconsultation network. Histopathology, 73(5), 777-783. http://doi.org/10.1111/his.13673

- Begley, C.G., \& Ellis, L.M. (2012). Raise standards for preclinical cancer research. Nature, 483, 531-533.

- Benke, K., \& Benke, G. (2018). Artificial Intelligence and Big Data in Public Health. International Journal of Environmental Research and Public Health, 15(12), 1-9. http://doi.org/10.3390/ijerph15122796

- Bizzego, A., Bussola, N., Chierici, M., Maggio, V., Francescatto, M., Cima, L... Furlanello, C. (2019). Evaluating reproducibility of Al algorithms in digital pathology with
DAPPER. PLOS
computational
biology, 15(3),
$1-24$. https://doi.org/10.1371/journal.pcbi.1006269

- Carmona-Serrano, N., López-Belmonte, J., Cuesta-Gómez, J.-L., \& Moreno-Guerrero, A.J. (2020). Documentary Analysis of the Scientific Literature on Autism and Technology in Web of Science. Brain Sciences, 10(12), 1-20. https://doi.org/10.3390/brainsci10120985

- Carmona-Serrano, N., López-Belmonte, J., López-Núñez, J.-A., \& Moreno-Guerrero, A.-J. (2020). Trends in autism research in the field of education in Web of Science: A bibliometric study. Brain Sciences, 10(12), 1-22. https://doi.org/10.3390/brainsci10121018

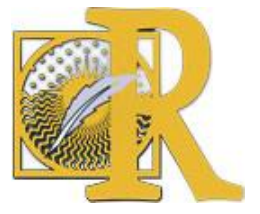

Fecha de recepción: 26-05-2020 Fecha de aceptación: 30-05-2020 López-Belmonte, J., Segura-Robles, A., Cho, W. C., Parra-González, M. E. \& Moreno-Guerrero, A. J. (2021) ¿Qué enseña la literatura sobre patología digital? Un estudio bibliométrico en Web of Science International Journal of Educational Research and Innovation (IJERI), 16, 106- 121 ISSN: 2386-4303 DOI https://doi.org/10.46661/ijeri.4918 
- Carmona-Serrano, N., Moreno-Guerrero, A.-J., Marín-Marín, J.-A., \& López-Belmonte, J. (2021). Evolution of the Autism Literature and the Influence of Parents: A Scientific Mapping in Web of Science. Brain Sciences, 11(1), 1-16. https://doi.org/10.3390/brainsci11010074

- Corredor, G., Whitney, J., Arias, V., Madabhushi, A., \& Romero, E. (2017). Training a celllevel classifier for detecting basal-cell carcinoma by combining human visual attention maps with low-level handcrafted features. Journal of Medical Imaging, 4(2), 1-15. https://doi.org/10.1117/1.JMl.4.2.021105

- Fauzi, M.F.A., Chen, W., Knight, D., Hampel, H., Frankel, W.L., \& Gurcan, M.N. (2019). Tumor Budding Detection System in Whole Slide Pathology Images. Journal of Medical System, 44(38), 1-10. https://doi.org/10.1007/s10916-019-1515-y

- Holliday, D.L., \& Speirs, V. (2011). Choosing the right cell line for breast cancer research. Breast Cancer Research, 13(4), 1-7. https://doi.org/10.1186/bcr2889

- Hsieh, W.-H., Chiu, W.-T., Lee, Y.-S., \& Ho, Y.-S. (2004). Bibliometric analysis of Patent Ductus Arteriosus treatments. Scientometrics, 60, 105-215. https://doi.org/10.1023/B:SCIE.0000027793.12866.58

- Klimov, S., Miligy, I.M., Gertych, A., Jiang, Y., Toss, M.S., Rida, P... Aneja, R. (2019) A whole slide image-based machine learning approach to predict ductal carcinoma in situ (DCIS) recurrence risk. Breast Cancer Research, 21(1), 1-19. https://doi.org/10.1186/s13058-019-1165-5

- López-Belmonte, J., Marín-Marín J.A., Soler-Costa, R., and Moreno-Guerrero, A.J. (2020). Arduino Advances in Web of Science. A Scientific Mapping of Literary Production. IEEE Access, 8, 128674-128682. https://doi.org/10.1109/ACCESS.2020.3008572

- López-Belmonte, J., Moreno-Guerrero, A.J., López-Núñez, J.A., \& Hinojo-Lucena, F.J. (2020). Augmented Reality in education. A scientific mapping in Web of Science. Interactive learning environments, 1-15. https://doi.org/10.1080/10494820.2020.1859546

- López-Belmonte, J., Moreno-Guerrero, A.J., López-Núñez, J.A., \& Pozo-Sánchez, S. (2019). Analysis of the Productive, Structural, and Dynamic Development of Augmented Reality in Higher Education Research on the Web of Science. Applied Science, 9(24), 121. https://doi.org/10.3390/app9245306

- López-Belmonte, J., Parra-González, M.E., Segura-Robles, A., and Pozo-Sánchez, S. (2020). Scientific Mapping of Gamification in Web of Science. European Journal of Investigation in Health, Psychology and Education, 10(3), 832-847. https://doi.org/10.3390/ejihpe10030060

- López-Belmonte, J., Segura-Robles, A., Moreno-Guerrero, A.-J., \& Parra-González, M.-E. (2021). Projection of E-Learning in Higher Education: A Study of Its Scientific Production in Web of Science. European Journal of Investigation in Health, Psychology and Education, 11(1), 20-32. https://doi.org/10.3390/ejihpe11010003

- López-Belmonte, J., Segura-Robles, A., Moreno-Guerrero, A.-J., \& Parra-González, M.-E. (2021). Robotics in education: A scientific mapping of the literature in Web of Science. Electronics, 10(3), 1-18. https://doi.org/10.3390/electronics10030291

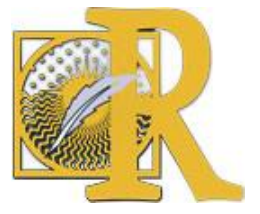


- López-Belmonte, J., Segura-Robles, A., Moreno-Guerrero, A.J., \& Parra-González, M.E. (2020). Machine Learning and Big Data in the Impact Literature. A Bibliometric Review with Scientific Mapping in Web of Science. Symmetry, 12(2), 1-15. https://doi.org/10.3390/sym12040495

- López-Núñez, J.A., López-Belmonte, J., Moreno-Guerrero, A.J., Ramos, M., \& HinojoLucena, F.J. (2020). Education and Diet in the Scientific Literature: A Study of the Productive, Structural, and Dynamic Development in Web of Science. Sustainability, 12(2), 1-17. https://doi.org/10.3390/su12124838

- Lugli, A., Kirsch, R., Ajioka, Y., Bosman, F., Cathomas, G., Dawson, H... Quirke, P. (2017). Recommendations for reporting tumor budding in colorectal cancer based on the International Tumor Budding Consensus Conference (ITBCC) 2016. Modern Pathology, 30(9), 1299-1311. https://doi.org/10.1038/modpathol.2017.46

- Majo, J., Klinkhammer, B.M., Boor, P., \& Tiniakos, D. (2019). Pathology and natural history of organ fibrosis. Current Opinion in Pharmacology, 49, 82-89. https://doi.org/10.1016/j.coph.2019.09.009

- Moreno-Guerrero, A.J., Gómez-García, G., López-Belmonte, J., \& Rodríguez-Jiménez, C. (2020). Internet Addiction in the Web of Science Database: A Review of the Literature with Scientific Mapping. International Journal of Environmental Research and Public Health, 17(8), 1-17. https://doi.org/10.3390/ijerph17082753

- Moreno-Guerrero, A.J., López-Belmonte, J., Marín-Marín, J.A. \& Soler-Costa, R. (2020). Scientific development of educational artificial intelligence in Web of Science. Future Internet, 12(8), 1-18. https://doi.org/10.3390/fi12080124

- Mukundan, R. (2019). Analysis of Image Feature Characteristics for Automated Scoring of HER2 in Histology Slides. Journal of Imaging, 5(3), 1-12. https://doi.org/10.3390/jimaging5030035

- Naylor, P., Laé, M., Reyal, F., \& Walter, T. (2018). Segmentation of nuclei in histopathology images by deep regression of the distance map. IEEE transactions on medical imaging, 38(2), 448-459. https://doi.org/10.1109/TMl.2018.2865709

- Norazman, S.H.B., Nakamura, T., Kimura, F., \& Yamaguchi, M. (2019). Analysis of quantitative phase obtained by digital holography on H\&E-stained pathological samples. Artificial Life and Robotics, 24(1), 38-43. https://doi.org/10.1007/s10015-0180468-4

- Parra-González, M., Segura-Robles, A., Vicente-Bújez, M., \& López-Belmonte, J. (2020). Production Analysis and Scientific Mapping on Active Methodologies in Web of Science. International Journal Of Emerging Technologies In Learning (IJET), 15(20), pp. 71-86. http://dx.doi.org/10.3991/ijet.v15i20.15619

- Patra, S.K., Bhattacharya, P., \& Verma, N. (2006). Bibliometric Study of Literature on Bibliometrics. DESIDOC Journal of Library \& Information Technology, 26(1), 27-32. https://doi.org/10.14429/djlit.26.1.3672

- Rodríguez-García, A.M., López-Belmonte, J., Agreda, M., \& Moreno-Guerrero, A.J. (2019) Productive, Structural and Dynamic Study of the Concept of Sustainability in the Educational Field. Sustainability, 11(20), 1-12. https://doi.org/10.3390/su11205613

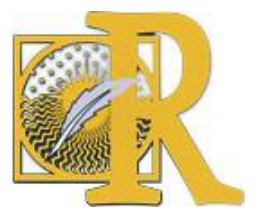

Fecha de recepción: 26-05-2020 Fecha de aceptación: 30-05-2020 
- Saxena, P., \& Goyal, A. (2019). Study of Computerized Segmentation \& Classification Techniques: An Application to Histopathological Imagery. Journal of Computing and Informatics, 43(4), 561-572. https://doi.org/10.31449/inf.v43i4.2142

- Segura-Robles, A., Moreno-Guerrero, A.J., Parra-González, E., \& López-Belmonte, J. (2020). Review of Research Trends in Learning and the Internet in Higher Education. Social Sciences, 9(6), 1-16. https://doi.org/10.3390/socsci9060101

- Soler-Costa, R., Moreno-Guerrero, A.-J., López-Belmonte, J., \& Marín-Marín, J.-A. (2021). Co-Word Analysis and Academic Performance of the Term TPACK in Web of Science. Sustainability, 13(3), 1-20. https://doi.org/10.3390/su13031481

- Tavolara, T.E., Khan, M.K., Arole, V., Chen, W., Frankel, W., \& Gurcan, M.N. (2019) A modular cGAN classification framework: Application to colorectal tumor detection. Scientific Reports, 9, 1-8.

- Williams, B.J., Bottoms, D., Clark, D., \& Treanor, D. (2019). Future-proofing pathology part 2: building a business case for digital pathology. Journal of clinical pathology, 72(3), 198205. https://doi.org/10.1136/jclinpath-2017-204926

- Zaidi, M., Fu, F., Cojocari, D., McKee, T.D., \& Wouter, B.G. (2019). Quantitative Visualization of Hypoxia and Proliferation Gradients Within Histological Tissue Sections.

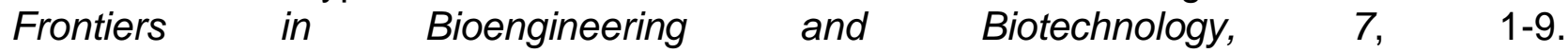
https://doi.org/10.3389/fbioe.2019.00397

- Zwanenburg, A., Vallières, M., Abdalah, M.A., Aerts, H.J.W.L., Andrearczyk, V., Ashrafinia, S..., Löck, S. (2020) The Image Biomarker Standardization Initiative: Standardized Quantitative Radiomics for High-Throughput Image-based Phenotyping. Radiology, 295(2), 1-16. https://doi.org/10.1148/radiol.2020191145 